\title{
The difficult act of balancing financial and academic performance: Product adaptation strategies at university branch campuses
}

\author{
Ali Bhayania \\ aFaculty of Business, University of Wollongong Dubai, United Arab Emirates, alibhayani@uowdubai.ac.ae.
}

Received: 24 June 2019, revised: 9 November 2019, accepted: 25 November 2019, published: 8 December 2019.

\begin{abstract}
Adapting a product to suit local requirements is a well-known international marketing strategy. Branch campuses generally adapt programs to suit local requirements. However, the academic fraternity has resisted adaptation on concerns about the dilution of academic standards. This study uses data from five branch campuses to examine the link between adaptation and financial and academic performance. The results indicate that adaption leads to increased financial performance but does not maintain academic standards. The study recommends strategies to maintain a balance between an ethnocentric approach, which calls for similar academic standards, and a geocentric approach, which requires adaptation.
\end{abstract}

Keywords: Higher education, internationalization, product adaptation, branch campuses, academic standards

JEL codes: D11, D21, D40, D83, F23, I23, M31

\section{INTRODUCTION}

Universities are looking to internationalize to target worldwide segments with their program offerings (Bhayani, 2015; Nelson Oly Ndubisi, Naidoo, \& Wu, 2014). In order to maintain academic standards, higher education (HE) as a product, needs to be standardized in offshore markets, where regulation is limited (Lieven \& Martin, 2006). On the other hand, Kerr (1990) argues that due to divergence in educational systems across the world, universities are expected to adapt their products in accordance with the host countries. The adaptation debate overlooked the fact that universities cannot be compared to commercial firms. This is because, a commercial firm's focal point is the consumer and it is run by senior management, whose objectives are to generate an economic surplus (Sugden, 2004) and to function like multinational corporations (Marginson, 2013). Furthermore, commercial offshore locations, in order to achieve economic efficiency and augment revenues, usually offer adapted and many times sub-standard products that satisfy the consumer (Bhayani, 2014; Nixon, Scullion, \& Hearn, 2016). Existing research regarding adaptation has generated inconclusive results with regard to economic efficiency (Tan \& Sousa, 2013).

Moreover, research discussing product adaptation primarily deals with products marketed by multinational corporations. These studies might not be able to encapsulate intricacies associated with higher education services because it is not as simple as satisfying the consumer, the students, and generation of economic surplus (Naidoo, Sankar, \& Ekant, 2011). Universities considering internationalization need to solve the product adaptation dilemma so they can predict the consequences of their strategy on financial and academic performance. Studies that have explored HE product adaptation (Hsuan-Fu \& Chia-Chi, 2008), have overlooked the impact of product adaptation on financial performance. This study would breach this gap by providing exploratory research with regards to assessing the international marketing strategies of the universities.

Another motivation for this study is to overcome the obsession of scholars to emphasize on proof-driven research that ignores the context of the study (Redding, 2005). Although there has been an increase in a number of studies that have stated that the context is not only complex and dynamic but also multi-dimensional (Michailova, 2011; Piekkari, Welch, \& Paavilainen, 2008; Poulis, Poulis, \& Plakoyiannaki, 2013; Sminia, 2015). Therefore, this study aims to breach this gap in the literature by studying international product strategies in a specific context and developing an understanding-driven model. HE in International Business (IB) literature is 
an under-researched context. This study provides empirical data regarding the non-profit sector which assesses not only the financial performance of the university but also the academic quality. The well-functioning international HE market of Dubai (UAE) provides rich data that can contribute to the IB literature. This data can answer the call for investigating adaptation in a foreign context if it investigates a contextually-specific environment of HE (Theodosiou \& Leonidou, 2003).

The paper includes literature regarding international product strategies in general and in HE-related contexts and the methodology used in this study. Discussion of the results and implications for practice are discussed towards the end of the paper.

\section{LITERATURE REVIEW}

One of the dilemmas which international managers face is developing a global product or adapting an existing product to specific host markets (Powers \& Loyka, 2010). IB literature has many papers arguing that standardization provides better performance. These studies argue that markets and consumer needs are becoming more similar (Kravets \& Sandikci, 2014) due to the growth of ICT (Information and Communications Technology) and the emergence of global market segments (Tan \& Sousa, 2013). Proponents of standardization have argued that this strategy allows for economies of scale and projects a coherent image of the firm (Kravets \& Sandikci, 2014). On the other side of the spectrum, proponents of adaptation have argued that firms need to adapt to the isomorphic pressure emanating from host countries due to variation in consumer taste and preference, regulation, and culture (Magnusson, Westjohn, Semenov, Randrianasolo, \& Zdravkovic, 2013; Theodosiou \& Leonidou, 2003). The stress faced by universities in international markets is not just cost economization but long-term profitability which can be achieved via differentiation.

While industrial products prefer to standardize (R. P. Lee, 2010), there are conflicting preferences when it comes to consumer products (C. Lee \& Griffith, 2004). Regardless, unique products that serve special needs are adapted, (Helm \& Gritsch, 2014) and this might be the case with HE services. Process, which is an integral part of the product, is generally standardized in firms that select the hierarchical mode of market entry, (Kraus, Ambos, Eggers, \& Cesinger, 2015) but the people aspect is mostly adapted (Tan \& Sousa, 2013).

The strategies used to adapt products have also produced conflicting results in the literature (Tan \& Sousa, 2013). In a study on factors leading to adaptation, Vrontis, Thrassou, and Lamprianou (2009) found that significant factors leading to adaptation include market development, different physical conditions, and political and legal framework. They also suggest that there are peripheral factors that lead to adaptation such as differences in culture, economic conditions, consumer perceptions, competition, and marketing infrastructure.

The strategy of a firm has an impact on its performance. Large firms with substantial market penetration and higher levels of coordination from headquarters adopt standardization to achieve a higher level of performance (Schilke, Reimann, \& Thomas, 2009). In a study focusing on how the firms adapt to the local market conditions when their performance deteriorates, Lages, Mata, and Griffith (2013) found that competition is the key factor that moderates the performance of the standardized product offering. Another study found that the firms that adapt their products to local market conditions display higher performance (Brouthers, O'Donnell, \& Keig, 2013).

\section{The Higher Education Context}

Transformation of HE into a transnational business model has led to an expansion in the form of branch campuses that adopt the franchise model or hierarchy (Wilkins \& Huisman, 2012). Foreign student recruitment and branch campuses provide revenues to universities (Bolsmann \& Miller, 2008). Branch campuses have the option of either to standardize their product offerings or adapt them to the local market based on the framework provided by Ghoshal (1987).

A branch campus needs to maintain external legitimacy by localizing the offering based on the isomorphic pressure created by universities and colleges in the host country (Kostova \& Roth, 2002). Branch campuses must also maintain internal legitimacy by complying with policies and practices prescribed by the home campus. and become idiosyncratic to their host country universities. These dual institutional pressures become more evident when organizations, like universities, deliver positional goods that portray a public image and carry reputation and prestige (Jonathan, 1990), resulting in universities scrambling for reputation (Van Vught, 2008). Transnational universities not only rely on the reputation of their home country campus but also on their country of origin. This leads students to assume that the program offered at the branch campus is identical to the home campus in terms of quality. However, it is not always possible to offer an identical learning experience at home and branch campus due to cultural differences (Tikly, 2004).

When offering courses, the curriculum tends to be standardized due to isomorphic pressure, quality control and positional status, but centralizing the decision at the home campus can infringe on academic freedom (Mayson 
\& Schapper, 2012) and can be interpreted as cultural imperialism and ethnocentric approach (Green, Kinser, \& Eckel, 2008). Another component of the transnational offering is staffing; branch campuses need to adapt due to the high cost of secondment (Shams \& Huisman, 2016). Further, they argue that the academic staff play an important role in creating a similar learning experience with regards to teaching and research. Creating academic infrastructure without home campus faculty members in a difficult recruitment environment poses a challenge to standardization (Chapman, Austin, Farah, Wilson, \& Ridge, 2014).

Although the academic community prefers standardization to maintain academic integrity and avoid commercialization (Naidoo et al., 2011), however staffing issues and focusing on cutting costs impedes the creation of academic infrastructure (Marginson, 2013). Adaptation is a predominant amongst UK universities, as found in the study by Healey (2018), due to isomorphic pressure from the host country.

In a more recent study undertaken by OBHE, Garrett (2018) notes that universities focus on quality over profit but the main goal is financial sustainability. Dubai, as the host country, brings along an isomorphic pressure on universities to be financially viable. This is because many unviable universities were forced to shut down or wind down their operations in Dubai (OBHE/C-BERT, 2016). Consequently, universities are often forced to adapt their offerings to ensure commercial viability by focusing on student numbers and operating surplus (Fielden, 2017).

Even though transnational HE is increasing, there is barely any research that has investigated how universities can find a balance between standardization and adaptation and understand their strategy's impact on academic and financial performance. (For a literature review see (Kosmützky \& Putty, 2015). Thus, the transnational HE context would be a significant addition to the growing IB and HE literature.

\section{METHODS}

IB research has traditionally considered context as impeding variables that need to be controlled (Harvey \& Myers, 1995) and therefore, most of the studies have been decontextualized. However, contextual factors related to organization, environment, and field of study do play a role in understanding a phenomenon (Buchanan \& Bryman, 2007). Therefore, dynamic factors such as culture and events can be considered using case study research (Ragin, 1992), where an interpretive approach would explain a particular phenomenon (Alvesson \& Sandberg, 2011; Bamberger \& Pratt, 2010). Therefore, this study is a context-embedded reconceptualization of the adaptation debate as existing conflicting results have created a gap (Dow \& Karunaratna, 2006) which calls for studying the phenomenon in a specific HE domain. Moreover, a few studies examining international strategies of universities have erred in the development of hypothesis or design of structured questionnaires used by those who have a positivist approach. Therefore, the qualitative approach works better in cases where the objective is to construct a theory (Gotsi, Lopez, \& Andriopoulos, 2011). This study uses a case study approach which, as per Poulis et al. (2013), can provide reliable results if purposeful sampling is implemented and that the sampling is complemented by secondary data.

Therefore, instead of using a literal replication approach, where the cases predicting the same results are adopted (Yin, 2003), a purposeful sampling (Silverman, 2006) approach leads to studying a variety of branch campuses from different countries which offer credit-bearing degree programs (undergraduate and postgraduate). Another criterion for selecting the case studies was the performance which was derived from secondary research. Three out of the five branch campuses were considered to be successful (more than 500 students in their undergraduate and postgraduate degree programs), while the other two had less than 200 students (the exact number of students or even approximate figures kept confidential, in order to maintain anonymity). Code U1, U2, and U3 denote financially successful universities while code U4 and U5 denote the not-so-successful ones. Samples include only those branch campuses that were established prior to 2010. The study used semi-structured interviews with key decision-makers both at home and branch campus level.

One of the reasons for selecting UAE for this study was the presence of the highest number of branch campuses (40 in total) (OBHE/C-BERT, 2016) from different countries that are traditional exporters of teaching-based HE. Interviews provided rich data that provided each participant's interpretation of the environment and consequently enhanced the understanding of the subject. Interview guide including a set of questions (see appendix) was prepared from the literature review and analysis thereafter followed the themes that emerged from the literature review (Krippendorff, 2012). A total of 21 interviews spanning an average of 52 minutes in length included director of administration, director of academic affairs, marketing managers, and faculty from the case study branch campuses. Corporate elites were the data collection method (Conti \& O'Neil, 2007). Website search and press releases and information on the public domain were used before and after the interviews to compare the responses and triangulate the information (Denzin, 2012). After the interviews, the transcripts were provided to the participants for feedback and further comments, if any. 
Content analysis using NVivo was used to analyze interview data by classifying the data based on their themes (Krippendorff, 2012). The themes and patterns from the interviews were compared to the existing theories to synthesize the data (Garner \& Scott, 2013), which helped clarify the relationships between constructs (Spiggle, 1994). This ensured that the findings could be considered credible, reliable, and trustworthy (Hesse-Biber \& Leavy, 2006). The financial performance measure was qualitative, as reported by the participants because it was not possible to get financial data from the branch campuses. Also, the names of the institutions were kept anonymous and all information that might lead to indicate any specific university has been omitted to avoid the universities from being identified in the small market of Dubai.

\section{ANALYSIS AND RESULTS}

The findings have been organized along with the five themes that emerged from the interview data. A summary is presented in Table 1.

\section{a) Product and Brand Name (Courses and Programs)}

Courses and programs offered at branch campuses are substantially less than what is offered at the home campus. This is because the product mix is determined by the needs of the target market and the potential for financial surplus. One of the universities explained their product offerings thus:

"There was an email from the vice president, responsible for international affairs to all the deans indicating opening up of the branch campus in Dubai. Seven deans attended the meeting and five agreed to offer their programs in Dubai. There was no market research to determine the student's preference or market demand. The result was very evident. Out of the five programs, only two are able to attract students. Others are just a burden" (Administrator, U4)

Resistance from the academic community to offer the program at branch campuses was the predominant reason for limited program offerings at $\mathrm{U} 4$ and $\mathrm{U} 5$ and this impacted their financial performance as well. Another reason for limited product offering was the lack of staffing to deliver the programs as explained by one of the faculty members:

"Faculty didn't have enough staff to deliver and monitor the programs in Dubai. It's not the issue of market potential but the scarcity of faculty resources and capabilities to deliver programs, so far away from the home campus" (Academic, U4).

On the other hand, two universities continuously conducted market research and offered programs that were in demand and potential to attract student numbers and even developing new programs to serve the market demand while discontinuing programs that had a negative surplus. As higher education is a specialized product serving unique consumer needs, the adaptation of the product mix to the student's need is in line with the findings of Helm and Gritsch (2014).

Another issue with regards to the product mix (very specific details of the product mix are not elaborated as it would result in loss of anonymity) is the adaptation of the program itself (ex. courses like Business Law need adaptation). But, four out of five universities did not adopt either due to the cost of adaptation or to maintain equivalency to the home country:

"The courses are kept at the same level as (home country) due to the equivalency requirements of the accrediting agencies. Further, we are offering a (home country) degree and therefore needs to offer exactly the same course that is offered on the home campus" (Faculty head, U1)

Another interviewee explained thus:

"The course is slightly adapted to incorporate country and regional contents. We use textbooks adapted to Middle Eastern edition whenever it's appropriate to do so. Our faculty members write the case studies which pertain to regional companies". (Faculty head, U3)

Interviewees at U3 explained that their university has contended with mild adaptation of the overall program, courses, and course contents. However, in some cases, a mandatory for example, a new course titled Islamic Culture is offered as part of the locally accredited undergraduate program. In four case study institutions, adaptation is driven mostly by the legal requirements and not based on consumer preferences or market demand (employers) which is consistent with the literature (Theodosiou \& Leonidou, 2003). One of the respondents from U3 explained that accreditation requirements in UAE call for local adaptation but the branch campuses replicate the courses from home campus making cosmetic changes to the reading lists.

New programs specifically developed for the Dubai campus, based on the market demand, were found only in one university (U1). However, one of the interviewees expressed concern that the program numbers are still 
less and it would take substantial effort to match the quality with other programs delivered at the campus as organizational learning associated with the program are absent.

The brand name of the universities is slightly adapted by putting the word 'Dubai' after the name of the university or putting the words 'in Dubai' or 'of Dubai'. One of the sample institutions kept the name as it is in the home country without adding the word Dubai. The logo was kept the same as the home country in U3 and U5 but mildly adapted to include the word Dubai in U1, U2, and U4. Brand name standardization is a dominant pattern observed in the literature (Vrontis et al., 2009) and is followed in HE for leverage purposes.

\section{b) Curriculum and Assessments}

In all five case study institutions, the curriculum was set at the home campus. However, one of the case study institutions, had to adapt the curriculum due to local accreditation requirements while providing limited freedom to academics to localize the courses. U4 and U5, on the other end of the spectrum, maintained standardized course outlines. Remaining two universities adapted superficially. In U1, U2, and U3, teaching materials were selected by local faculty with approval from the home campus. In all cases, the curriculum taught at the branch campuses passed through the QA process in the home country. In one of the cases, at both home and host country level.

With regards to assessments, U2, U4, and $\mathrm{U} 5$ run the exams at the same time, as the home country campus, due to the similar exams. QA procedure, in all case study institutions, included sending a sample of the papers back to the home country. In the case of $\mathrm{U} 1$ and $\mathrm{U} 2$, auditors flew in before the results are declared to audit the marking and ensuring the course delivery meets the quality criterion. But the respondents expressed concern that overall quality standards are lower than the home campus.

\section{c) People (faculty and administrative staff)}

With regard to academic staff, all universities have adopted and hired locally. Even the human resources policies are adapted locally to conform to the legal and business requirements of the region. The recruitment policies with regards to academic staff have been explained thus:

"At home campus research effectiveness is the main criteria for selection but here it's difficult to get researchactive faculty members locally. Here teaching is the main focus because we don't get research dollars" (Academic, U4)

However, another head of the faculty had a different point of view:

"We hire research-active staff internationally. Our policy is clear: teaching is informed by research" (Academic, U2)

Respondents pointed out that teaching is the main activity and their reporting line is both in Dubai and at the home campus where they have a mentor from the faculty who approves and does QA as also identified in a study of (Shams \& Huisman, 2016). While local campuses had the autonomy to recruit staff; they were assigned to a mentor at the home campus. All universities preferred recruiting staff locally due to the high cost of the home campus staff and reluctance on part of the faculty to relocate. U5, in meeting student's preferences, had a majority of faculty from home campus. However, these high costs led to the dismal financial performance of the campus.

Another adaptation is the administrative staff which is recruited locally as well. But the significant aspect is the top management i.e. the head of the campus. U1, U4, and U5 have the campus directors seconded from the home campus. One of the respondents clarified:

"The head of the campus is now deputed from (home country) but this was not the case when the campus started. Founding Head of the campus was professor ..., who was recruited internationally. He was very effective and credited with the success of the campus. In initial years, the campus was struggling but the team understood local differences and changed quickly" (Academic, U1)

Adaptation is a key was underlined by a faculty member of $U 4$ campus which had Head of the Campus (declined the invitation to interview) deputed from the home campus:

"Campus is struggling due to the Director who is an excellent academic but with no sense on how to conduct the business. ... Focuses on research rather than getting students. Students are not coming in and there is no plan in place how to tackle the situation" (Academic, U4)

The respondents from both $\mathrm{U} 4$ and $\mathrm{U} 5$ blamed the lack of business sense of the people at the helm for not understanding the business culture and adapting accordingly. Analysis of the respondents indicates that campuses that had seconded faculty from home campus to head the campus were not financially successful, 
as they had no experience of running campus like a business. Rather, adopting an ethnocentric approach by replicating the home campus-style of governance led to poor management of the campus. This is because the home country environment is usually characterized by lesser competition. A financially viable campus requires government support or marketing orientation. In the absence of government support in Dubai, campuses need to have a marketing orientation in their management.

\section{d) Processes}

Processes at the universities are broadly divided into academic and administrative. U1, U4, and U5 have adopted a standardized approach to academic processes to ensure quality. One of the respondents from U5, where a local partner plays an important role, commented:

"We have full control over the academic processes. [Our] local partner takes care of marketing, finance, and facilities management. All policies are the same as that on the home campus" (Academic, U5)

Respondents from U2 affirmed that the university has adopted the home country processes to match the local accreditation needs. On the other hand, U3 develops policies after consulting local partners, but the home campus approves most of the academic decisions and policies.

Except for U4 and U5, all the case study institutions have adapted their administrative processes to local legal requirements and business culture. One of the respondents said:

"We had to devise plan wherein the student can pay the fees in installments, give sibling discount and provide transportation service. This was quite a new experience for us." (Administrator, U1)

One of the administrators explained how the attendance system which was non-existent on the home campus was installed for all administrative staff. Apart from this, human resources policies were generally adapted to match the legal requirements.

\section{e) Performance}

Performance is the last theme in the discussion between performance and adaptation. Here the researcher has provided a score to state the level of adaptation (See Table 1). Based on this, the product of U2 is mostly adapted closely followed by U1 and U3. But, U4 and U5 have the least adapted product.

In the case of U4, the standardized approach emanates from the hierarchical entry mode adopted by the university. There is no local partner and most of the decisions are made at the home campus. University is a public institution in the home country with a sizable number of students but lacks marketing orientation due to the ethnocentric approach. Lack of marketing orientation resulted in very few student numbers resulting in financial failure. One of the respondents summarised the situation:

"You cannot control university from ...... [home country] and expect results. The staff here have a typical 9 to 5 approach and lacks drive. The courses are not relevant for the employment market of Dubai and the campus looks like a crammed office space" (Academic, U4).

However, its academic performance in terms of drop-out ratio and pass rates were much better than U1, U2, and U3.

In the case of U5, the performance could have been better with a local partner managing the marketing, finance, and facilities as per respondents. However, its product mix, location, high-cost structure, and consequently higher prices resulted in very few student numbers. University was slow to react to the dynamic market of Dubai as characterized by an academic:

".... the market is highly competitive. Mostly all universities offered discounts and fee rebates in the form of scholarships. It took them about a year to get approval to offer scholarships. But it was too late" (Academic, U5)

In the case of U5 also, the academic performance was much better due to standardized products, people and processes. Standardization was helpful in generating superior academic performance but it came at the cost of financial performance.

U3 had an excellent financial performance but a below-average academic performance. The product was adapted to the market of Dubai and local staff has substantial leverage in making decisions in both academic and administrative domains. However, academic performance is below average as explained by a respondent:

"Admissions requirements are too low and practically everyone with the ability to pay gets admitted. University's admission and assessment standards are substandard, and it reflects very badly on us" (Academic, U3).

$\mathrm{U} 1$ and $\mathrm{U} 2$ have adapted their product and are financially successful but academic performance is average as indicated by academics. While U1 has complete academic control at home campus, U2 has partial control at 
home campus. Both have a strong marketing orientation and adapts their product to remain competitive in line with the results of Brouthers et al. (2013). The governance structure is local but there is an oversight from the home campus. One of the respondents explained:

Table 1. Summary of Marketing Strategies of the Case Study Universities

\begin{tabular}{|c|c|c|c|c|c|}
\hline $\begin{array}{l}\text { Marketing } \\
\text { Strategy Element }\end{array}$ & U1 & U2 & U3 & U4 & U5 \\
\hline No of students & More than 500 & More than 500 & More than 500 & Less than 200 & Less than 200 \\
\hline Adaptation Score & 4 & 5 & 4 & 2 & 1 \\
\hline Program offered & $\begin{array}{l}\text { Adapted based } \\
\text { on market } \\
\text { research }\end{array}$ & $\begin{array}{l}\text { Adapted } \\
\text { based on } \\
\text { market } \\
\text { research }\end{array}$ & $\begin{array}{l}\text { Adapted based } \\
\text { on the Local } \\
\text { Partner's } \\
\text { assessment } \\
\end{array}$ & $\begin{array}{l}\text { Adapted based on } \\
\text { Availability of } \\
\text { Resources }\end{array}$ & $\begin{array}{l}\text { Based on Local } \\
\text { Partner's } \\
\text { assessment }\end{array}$ \\
\hline $\begin{array}{l}\text { Entry } \\
\text { Requirements }\end{array}$ & Adapted & Adapted & Adapted & Standard & Standard \\
\hline $\begin{array}{l}\text { Course /Course } \\
\text { Content }\end{array}$ & Standard & $\begin{array}{l}\text { Adapted to } \\
\text { match local } \\
\text { accreditation }\end{array}$ & $\begin{array}{l}\text { Mildly Adapted } \\
\text { in form of } \\
\text { Textbooks }\end{array}$ & Standard & Standard \\
\hline $\begin{array}{l}\text { New program } \\
\text { only for branch } \\
\text { campus }\end{array}$ & No & $\begin{array}{l}\text { Developed } \\
\text { New Program }\end{array}$ & (2) & No & No \\
\hline Program Delivery & $\begin{array}{l}\text { On-Site delivery } \\
\text { supported by } \\
\text { asynchronous } \\
\text { e-learning }\end{array}$ & $\begin{array}{l}\text { On-Site } \\
\text { delivery } \\
\text { supported by } \\
\text { asynchronous } \\
\text { e-learning }\end{array}$ & $\begin{array}{l}\text { On-Site delivery } \\
\text { supported by } \\
\text { asynchronous } \\
\text { e-learning }\end{array}$ & $\begin{array}{l}\text { Combination of on- } \\
\text { site and eLearning } \\
\text { (both synchronous } \\
\text { and asynchronous) }\end{array}$ & $\begin{array}{l}\text { On site and fly in } \\
\text { faculty for some } \\
\text { programs }\end{array}$ \\
\hline Academic Staff & $\begin{array}{l}\text { Recruited } \\
\text { locally }\end{array}$ & $\begin{array}{l}\text { Recruited } \\
\text { locally }\end{array}$ & $\begin{array}{l}\text { Recruited } \\
\text { locally }\end{array}$ & $\begin{array}{l}20 \% \text { from home } \\
\text { campus and } 80 \% \\
\text { local recruitment }\end{array}$ & $\begin{array}{l}80 \% \text { from home } \\
\text { campus and } 20 \% \\
\text { local recruitment }\end{array}$ \\
\hline $\begin{array}{l}\text { Administrative } \\
\text { Staff }\end{array}$ & $\begin{array}{l}\text { Recruited } \\
\text { locally }\end{array}$ & $\begin{array}{l}\text { Recruited } \\
\text { locally }\end{array}$ & $\begin{array}{l}\text { Recruited } \\
\text { locally }\end{array}$ & Recruited locally & Recruited locally \\
\hline Top Management & $\begin{array}{l}\text { Deputed from } \\
\text { Home Campus }\end{array}$ & $\begin{array}{l}\text { Recruited } \\
\text { locally }\end{array}$ & $\begin{array}{l}\text { Recruited } \\
\text { locally with input } \\
\text { from local } \\
\text { partner }\end{array}$ & $\begin{array}{l}\text { Deputed from } \\
\text { Home Campus }\end{array}$ & $\begin{array}{l}\text { Deputed from } \\
\text { Home Campus }\end{array}$ \\
\hline $\begin{array}{l}\text { Process } \\
\text { Academic }\end{array}$ & Standardised & $\begin{array}{l}\text { Home process } \\
\text { adapted to } \\
\text { match local } \\
\text { needs }\end{array}$ & $\begin{array}{l}\text { Locally } \\
\text { developed and } \\
\text { approved by } \\
\text { Home Campus }\end{array}$ & Standardized & Standardized \\
\hline $\begin{array}{l}\text { Process } \\
\text { Administrative }\end{array}$ & $\begin{array}{l}\text { Adapted to local } \\
\text { environment }\end{array}$ & $\begin{array}{l}\text { Developed } \\
\text { locally }\end{array}$ & $\begin{array}{l}\text { Locally } \\
\text { developed and } \\
\text { approved by } \\
\text { Home Campus }\end{array}$ & Standardized & Standardized \\
\hline $\begin{array}{l}\text { Academic } \\
\text { Performance }\end{array}$ & $\begin{array}{l}\text { Academic } \\
\text { standards lower } \\
\text { than home } \\
\text { campus }\end{array}$ & $\begin{array}{l}\text { Performance } \\
\text { is at lower } \\
\text { than home } \\
\text { campus }\end{array}$ & $\begin{array}{l}\text { Academic } \\
\text { standards lower } \\
\text { than home } \\
\text { campus }\end{array}$ & $\begin{array}{l}\text { Higher academic } \\
\text { standards }\end{array}$ & $\begin{array}{l}\text { Higher academic } \\
\text { standards }\end{array}$ \\
\hline $\begin{array}{l}\text { Financial } \\
\text { Performance } \\
\end{array}$ & Very Successful & Successful & Very Successful & Negative Cash flow & Negative cash flow \\
\hline \multicolumn{6}{|c|}{ Source: Own elaboration. } \\
\hline $\begin{array}{l}\text { "University is agg } \\
\text { focusing on gradu }\end{array}$ & ssive in its ma & $\begin{array}{l}\text { ting efforts } w \\
s \text { who have e }\end{array}$ & h a lot of emph & $\begin{array}{l}\text { is on sales. I wis } \\
\text { Academic, U1) }\end{array}$ & university can sté \\
\hline
\end{tabular}




\section{CONCLUSIONS}

The aim of the study was to explore how universities adapt to off-shore branch campuses. Even though universities are rapidly internationalizing (OBHE/C-BERT, 2016), the study of their international strategies is an under-researched topic. In a meta-analysis, Tan and Sousa (2013) found that the impact of adaptation of product and performance was an under-researched topic even in IB literature.

Adaptation covered in this study encompassed course content, course mix, admission requirements, faculty, and delivery processes. The main drivers of adaptation identified in this study pertain to legal requirements (accreditation), market demand and culture. From the above data, it seems that adaptation is crucial in order to enhance financial performance. But it is not necessary to the extent that academic performance is sacrificed to adapt to the needs of student-consumer. Practically all three financially successful universities have diluted admission or assessment requirements which have added to the concerns of academic fraternity. Academics have resisted adaptation which leads to lower academic standards and termed it as managerialism (Deem, 2001).

The negative financial results for U4 and U5 can be attributed to lower student numbers. The enrollment was low because the universities sought to maintain admission and assessment standards of their home countries. The national economy of UAE could be better strengthened by creating an academically-strong HE sector. Low student numbers at many universities could also be the result of students choosing to study abroad (Bhayani, 2014). To maintain financial viability, universities focus on the needs and preferences of consumers (students) and market demand rather than maintaining academic standards of the home campus (Naidoo et al., 2011). Other factors that might impact performance include leadership style, marketing capabilities, and role of local knowledge (Tan \& Sousa, 2013). But, maintaining home campus admission standards resulted in financial distress of $\mathrm{U} 4$ and $\mathrm{U} 5$. Another takeaway point of this study is the need for adapted leadership that has business management skills rather than academic accomplishments. One of the reasons identified by respondents from U4 was that the leadership was devoid of business acumen. Local recruitment of key staff who possessed local business insight contributed to the success of U1, U2, and U3.

Though adaptation is a common-sense approach in IB, this study demonstrated that higher education context is different. This is because universities not only care about financial success but also academic standards. There are several factors such as judgement of the campus head with regards to environment, fit between environment and strategy and the way the strategy is executed that leads to better performance which is also indicated in the study by Subramaniam and Hewett (2004) and Yaprak, Xu, and Cavusgil (2011) but governmental support and incentives would play a key role in order to ensure that academic standards are not diluted. Dubai's academic free zones could improve the narrow focus of seeing universities as a revenue source and provide funding for key infrastructure. These results again highlight the importance of context-sensitive studies.

\section{Limitations and Future Research}

One of the limitations of this study is the qualitative nature of the study where the emphasis is not on the generalizability of the results. Therefore, findings here need to be compared with similar style studies in other hubs of branch campuses like Qatar, Singapore, Hong Kong, and Malaysia. The results obtained can then be compared with this study to understand the contextual factors more clearly. Another issue with the study was trying to link adaptation to performance. Results here are indicative and did not suggest a definitive causal relationship between adaptation and performance. Future quantitative studies within HE context can try to establish the link between the variables. The study did not consider factors such as and physical distance nor did these factors emerge from the data. However, they are still important factors as identified in existing IB literature.

Another limitation of the single-country study is the external validity of the study. But as Leonidou, Katsikeas, and Samiee (2002) demonstrated in their meta-analytical review that single-country studies have external validity when cross-country comparisons were undertaken in meta-analytical studies and therefore it is not a significant issue. Considering the qualitative measure of performance might be regarded as a limitation as it does not give hard figures of sales, profitability, drop out ratio, pass rates, etc. However, there are studies that have taken the managerial judgement of export performance as an indication of performance (Diamantopoulos \& Kakkos, 2007; Madsen, 1998). In a study on Brazilian firms, Carneiro, Farias, da Rocha, and Ferreira da Silva (2016) defined how managers' assessment of export performance is a valid measure in absence of confidential financial data. Future research can investigate conceptualizing academic performance in a holistic manner which would include several measures of quality. Another area of future studies would be looking at the same university's branch campuses in different countries to understand adaptation in cultural and host country context. 
One of the major contributions of this study is that it will provide insight into the decision with regards to strategies in the HE sector. The study being cross-sectional has investigated strategies at one time. A longitudinal study would provide insights into how the strategies evolve in a dynamic environment.

\section{REFERENCES}

Alvesson, M., \& Sandberg, J. (2011). Generating research questions through problematization. Academy of management review, 36(2), 247-271. doi:10.5465/AMR.2011.59330882

Bamberger, P. A., \& Pratt, M. G. (2010). Moving forward by looking back: reclaiming unconventional research contexts and samples in organizational scholarship. Academy of Management Journal, 53(4), 665-671. doi:10.5465/AMJ.2010.52814357

Bhayani, A. (2014). The market route to higher education in UAE: its rationales and implications. International Review on Public and Nonprofit Marketing, 11(1), 75-87.

Bhayani, A. (2015). Building entrepreneurial universities in a specific culture-barriers and opportunities. International Journal of Nonprofit and Voluntary Sector Marketing, 20(4), 312-330.

Bolsmann, C., \& Miller, H. (2008). International student recruitment to universities in England: Discourse, rationales, and globalisation. Globalisation, Societies, and Education, 6(1), 75-88.

Brouthers, L. E., O'Donnell, E., \& Keig, D. L. (2013). Isomorphic pressures, peripheral product attributes and emerging market firm export performance. Management International Review, 53(5), 687-710.

Buchanan, D. A., \& Bryman, A. (2007). Contextualizing methods choice in organizational research. Organizational Research Methods, 10(3), 483-501.

Carneiro, J., Farias, I., da Rocha, A., \& Ferreira da Silva, J. (2016). How to measure export performance? Scholars' vs. practitioners' answers. Journal of Business Research, 69(2), $410-417$. doi:http://dx.doi.org/10.1016/j.jbusres.2015.06.046

Chapman, D., Austin, A., Farah, S., Wilson, E., \& Ridge, N. (2014). Academic Staff in the UAE: Unsettled Journey. Higher Education Policy, 27(1), 131-151. doi:10.1057/hep.2013.19

Conti, J. A., \& O'Neil, M. (2007). Studying power: Qualitative methods and the global elite. Qualitative Research, 7(1), 6382.

Deem, R. (2001). Globalization, new managerialism, academic capitalism and entrepreneurialism in universities; is the local dimension still important? Comparative education, 37(1), 7-20.

Denzin, N. K. (2012). Triangulation 2.0. Journal of Mixed Methods Research, 6(2), 80-88.

Diamantopoulos, A., \& Kakkos, N. (2007). Managerial assessments of export performance: conceptual framework and empirical illustration. Journal of International Marketing, 15(3), 1-31.

Dow, D., \& Karunaratna, A. (2006). Developing a multidimensional instrument to measure psychic distance stimuli. Journal of International Business Studies, 37(5), 578-602.

Fielden, J. (2017). Global: Financial Aspects of Offshore Activities Understanding Higher Education Internationalization (pp. 45-47): Springer.

Garner, R., \& Scott, G. M. (2013). Doing qualitative research: designs, methods, and techniques: Pearson Education.

Garrett, R. (2018). International branch campuses: Success factors. International Higher Education, (93), 14-16.

Ghoshal, S. (1987). Global strategy: An organizing framework. Strategic Management Journal, 8(8), 425-440.

Gotsi, M., Lopez, C., \& Andriopoulos, C. (2011). Building a country image through corporate image: exploring the factors that influence the image transfer. Journal of Strategic Marketing, 19(3), 255-272.

Green, M. F., Kinser, K., \& Eckel, P. D. (2008). On the ground overseas: US degree programs and branch campuses abroad. American Council on Education.

Harvey, L. J., \& Myers, M. D. (1995). Scholarship and practice: the contribution of ethnographic research methods to bridging the gap. Information Technology \& People, 8(3), 13-27.

Healey, N. M. (2018). The Optimal Global Integration-Local Responsiveness Tradeoff for an International Branch Campus. Research in Higher Education, 59(5), 623-649. Doi:10.1007/s11162-017-9480-0

Helm, R., \& Gritsch, S. (2014). Examining the influence of uncertainty on marketing mix strategy elements in emerging business to business export-markets. International Business Review, 23(2), 418-428.

Hesse-Biber, S. N., \& Leavy, P. (2006). The Practice of Qualitative Research. Thousand Oaks CA: Sage Publications.

Hsuan-Fu, H., \& Chia-Chi, H. (2008). Marketing mix formulation for higher education. The International Journal of Educational Management, 22(4), 328-340. doi:http://dx.doi.org/10.1108/09513540810875662

Jonathan, R. (1990). State Education Service or Prisoner's Dilemma: The 'Hidden Hand' as Source of Education Policy1. Educational Philosophy and Theory, 22(1), 16-24. doi:10.1111/j.1469-5812.1990.tb00421.x

Kerr, C. (1990). The Internationalization of Learning and the Nationalization of the Purposes of Higher Education: Two" Laws of Motion" in Conflict? European Journal of Education, 25(1), 5-22. 
Kosmützky, A., \& Putty, R. (2015). Transcending Borders and Traversing Boundaries. Journal of Studies in International Education, 20(1), 8-33. Doi:10.1177/1028315315604719

Kostova, T., \& Roth, K. (2002). Adoption of an organizational practice by subsidiaries of multinational corporations: institutional and relational effects. Academy of Management Journal, 45(1), 215-233. Doi:10.2307/3069293

Kraus, S., Ambos, T. C., Eggers, F., \& Cesinger, B. (2015). Distance and perceptions of risk in internationalization decisions. Journal of Business Research, 68(7), 1501-1505. doi:http://dx.doi.org/10.1016/j.jbusres.2015.01.041

Kravets, O., \& Sandikci, O. (2014). Competently ordinary: New middle class consumers in the emerging markets. Journal of Marketing, 78(4), 125-140.

Krippendorff, K. (2012). Content analysis: An introduction to its methodology: Sage.

Lages, L. F., Mata, J., \& Griffith, D. A. (2013). Change in international market strategy as a reaction to performance decline. Journal of Business Research, 66(12), 2600-2611. doi:http://dx.doi.org/10.1016/j.jbusres.2012.05.018

Lee, C., \& Griffith, D. A. (2004). The marketing strategy-performance relationship in an export-driven developing economy: A Korean illustration. International Marketing Review, 21(3), 321-334.

Lee, R. P. (2010). Extending the Environment-Strategy-Performance Framework: The roles of multinational corporation network strength, market responsiveness, and product innovation. Journal of International Marketing, 18(4), 58-73.

Leonidou, L. C., Katsikeas, C. S., \& Samiee, S. (2002). Marketing strategy determinants of export performance: a metaanalysis. Journal of Business Research, 55(1), 51-67.

Lieven, M., \& Martin, G. (2006). Higher Education in a Global Market: The Case of British Overseas Provision in Israel. Higher Education, 52(1), 41-68. doi:http://dx.doi.org/10.1007/s10734-004-6374-9

Madsen, T. K. (1998). Managerial judgment of export performance, 6(3), Journal of International Marketing, 82-93.

Magnusson, P., Westjohn, S. A., Semenov, A. V., Randrianasolo, A. A., \& Zdravkovic, S. (2013). The role of cultural intelligence in marketing adaptation and export performance. Journal of Marketing Research, 21(4), 44-61.

Marginson, S. (2013). The Lost Soul of Higher Education: Corporatization, the Assault on Academic Freedom, and the End of the American University [Book Review]. Labour History,105, 262-263.

Mayson, S., \& Schapper, J. (2012). Constructing teaching and research relations from the top: An analysis of senior manager discourses on research-led teaching. Higher Education, 64(4), 473-487.

Michailova, S. (2011). Contextualizing in International Business research: Why do we need more of it and how can we be better at it? Scandinavian Journal of Management, 27(1), 129-139. doi:http://dx.doi.org/10.1016/j.scaman.2010.11.003

Naidoo, R., Sankar, A., \& Ekant, V. (2011). The consumerist turn in higher education: Policy aspirations and outcomes. Journal of Marketing Management, 27(11-12), 1142-1162.

Nelson Oly Ndubisi, P., Naidoo, V., \& Wu, T. (2014). Innovations in marketing of higher education: Foreign market entry mode of not-for-profit universities. Journal of Business \& Industrial Marketing, 29(6), 546-558.

Nixon, E., Scullion, R., \& Hearn, R. (2016). Her majesty the student: marketised higher education and the narcissistic (dis)satisfactions of the student-consumer. Studies in Higher Education, 1-21. doi:10.1080/03075079.2016.1196353

OBHE/C-BERT. (2016). International Branch Campuses: Trends and Developments: The Observatory on Borderless Higher Education/Cross-Border Education ....

Piekkari, R., Welch, C., \& Paavilainen, E. (2008). The Case Study as a Disciplinary Convention. Organizational Research Methods, 12(3), 567-589. doi:10.1177/1094428108319905

Poulis, K., Poulis, E., \& Plakoyiannaki, E. (2013). The role of context in case study selection: An international business perspective. International Business Review, 22(1), 304-314. doi:http://dx.doi.org/10.1016/j.ibusrev.2012.04.003

Powers, T. L., \& Loyka, J. J. (2010). Adaptation of marketing mix elements in international markets. Journal of Global Marketing, 23(1), 65-79.

Ragin, C. C. (1992). Introduction: Cases of what is a case? 1-17.

Redding, G. (2005). The thick description and comparison of societal systems of capitalism. Journal of International Business Studies, 36(2), 123-155. doi:http://dx.doi.org/10.1057/palgrave.jibs.8400129

Schilke, O., Reimann, M., \& Thomas, J. S. (2009). When Does International Marketing Standardization Matter to Firm Performance? Journal of International Marketing, 17(4), 24-46. doi:10.1509/jimk.17.4.24

Shams, F., \& Huisman, J. (2016). The role of institutional dual embeddedness in the strategic local adaptation of international branch campuses: evidence from Malaysia and Singapore. Studies in Higher Education, 41(6), 955-970. doi:10.1080/03075079.2014.966669

Silverman, D. (2006). Interpreting qualitative data: methods for analysing talk, text, and interaction (3rd ed. Ed.). London: SAGE.

Sminia, H. (2015). Contextualized explanation in strategy research, Research Methods for Strategic Management, (pp. 96115), Routledge

Spiggle, S. (1994). Analysis and interpretation of qualitative data in consumer research. Journal of Consumer Research, 491-503. 
Subramaniam, M., \& Hewett, K. (2004). Balancing standardization and adaptation for product performance in international markets: testing the influence of headquarters-subsidiary contact and cooperation. MIR: Management International Review, 171-194.

Sugden, R. (2004). A Small Firm Approach to the Internationalisation of Universities: A Multinational Perspective. Higher Education Quarterly, 58(2-3), 114-135. doi:10.1111/j.1468-2273.2004.00264.x

Tan, Q., \& Sousa, C. M. (2013). International marketing standardization. Management International Review, 53(5), 711-739.

Theodosiou, M., \& Leonidou, L. C. (2003). Standardization versus adaptation of international marketing strategy: an integrative assessment of the empirical research. International Business Review, 12(2), 141-171. doi:http://dx.doi.org/10.1016/S0969-5931(02)00094-X

Tikly*, L. (2004). Education and the new imperialism. Comparative Education, 40(2), 173-198.

Van Vught, F. (2008). Mission diversity and reputation in higher education. Higher Education Policy, 21(2), $151-174$.

Vrontis, D., Thrassou, A., \& Lamprianou, I. (2009). International marketing adaptation versus standardisation of multinational companies. International Marketing Review, 26(4/5), 477-500. doi:http://dx.doi.org/10.1108/02651330910971995

Wilkins, S., \& Huisman, J. (2012). The international branch campus as a transnational strategy in higher education. Higher Education, 64(5), 627-645.

Yaprak, A., Xu, A. P. S., \& Cavusgil, A. P. E. (2011). Effective global strategy implementation. Management International Review, 51(2), 179-192.

Yin, R. K. (2003). Case study research: design and methods (3rd ed. ed.). Thousand Oaks, Calif. ; London: SAGE.

\section{APPENDIX 1.}

\section{Semi-structured interview questions}

1. To start with, can you please provide a description of the university's marketing strategies in Dubai?

2. What is the product mix (course and programs) and how the university decided what courses to offer at the Dubai campus? Market Research, consumer preference?

3. Does University adapts its program by incorporating course contests that take into account local and regional aspects? For example, courses like business law which might not be relevant to Dubai? Or any new courses for Dubai campus within the original program?

4. Did the university offer any new program specifically for the branch campus?

5. Why or why not the brand name got adapted?

6. On what basis the university decided about the fees?

7. What was the strategy with regard to pricing (fees)?

8. How the marketing and advertising strategy decision being made at the university?

9. Is the advertising made keeping in mind the local needs or made at home campus? Explain

10. How the university handles promotions and discounts?

11. How the university delivers programs? Does it make use of eLearning?

12. Are the academic, administrative and top management staff seconded from the home campus or recruited locally? What is the human resource strategy at the campus?

13. Does university adopt the academic and administrative processes from home campuses or devise them locally?

14. Servicescape (layout, color, interior design, building design) match the design at home campus?

15. How would you rate the academic and financial performance of the university? 